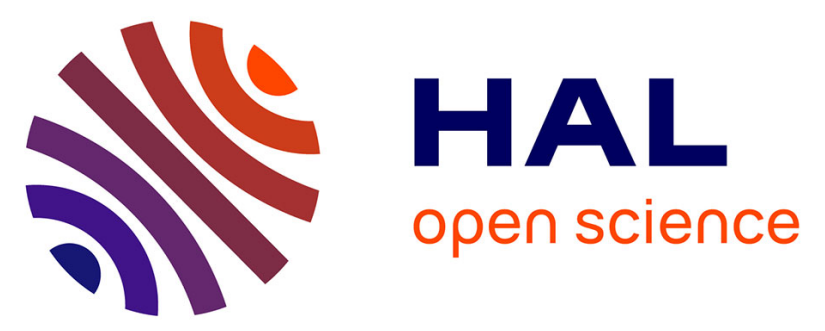

\title{
A Photochemical Approach to Pyridopyrroloquinoline Derivatives as New Potential Anticancer Agents
}

Pierre-Jean Aragon, Ange-Désiré Yapi, Frédéric Pinguet, Jean-Michel Chezal, Jean-Claude Teulade, Jean-Pierre Chapat, Yves Blache

\section{- To cite this version:}

Pierre-Jean Aragon, Ange-Désiré Yapi, Frédéric Pinguet, Jean-Michel Chezal, Jean-Claude Teulade, et al.. A Photochemical Approach to Pyridopyrroloquinoline Derivatives as New Potential Anticancer Agents. Chemical and Pharmaceutical Bulletin, 2004, 52, pp.659 - 663. 10.1248/cpb.52.659 . hal02384520

\section{HAL Id: hal-02384520 \\ https://hal.science/hal-02384520}

Submitted on 28 Nov 2019

HAL is a multi-disciplinary open access archive for the deposit and dissemination of scientific research documents, whether they are published or not. The documents may come from teaching and research institutions in France or abroad, or from public or private research centers.
L'archive ouverte pluridisciplinaire HAL, est destinée au dépôt et à la diffusion de documents scientifiques de niveau recherche, publiés ou non, émanant des établissements d'enseignement et de recherche français ou étrangers, des laboratoires publics ou privés. 


\title{
A Photochemical Approach to Pyridopyrroloquinoline Derivatives as New Potential Anticancer Agents
}

\author{
Pierre-Jean Aragon, ${ }^{a, b}$ Ange-Désiré Yapi, ${ }^{a}$ Frédéric Pinguet, ${ }^{b}$ Jean-Michel Chezal, ${ }^{c}$ \\ Jean-Claude Teulade, ${ }^{c}$ Jean-Pierre Chapat, ${ }^{a}$ and Yves Blache ${ }^{*}, d$ \\ ${ }^{a}$ Laboratoire de Chimie Organique Pharmaceutique, E.A. 2414, Faculté de Pharmacie; 15 avenue Charles Flahault, \\ 34060 Montpellier, France: ${ }^{b}$ Laboratoire d'Oncopharmacologie, Centre Régional de Lutte Contre le Cancer; Val \\ d'Aurelle, 34298 Montpellier cedex 05, France: ${ }^{c}$ Laboratoire de Chimie Organique Pharmaceutique, Faculté de \\ Pharmacie, UMR INSERM 484; 28 Place Henry Dunant, B.P. 38, 63001 Clermont-Ferrand, France: and ${ }^{d}$ Laboratoire de \\ chimie organique et thérapeutique, EA 3660, Unité de Molécules d'Intérêt Biologique, Faculté de Pharmacie; 7 boulevard \\ Jeanne d'Arc, BP 89700, 21079 Dijon, France. Received November 25, 2003; accepted February 26, 2004
}

Indoloquinoline alkaloid cryptolepine and pyridocarbazole alkaloid ellipticine are of great interest because in vitro and in vivo studies revealed their good cytotoxic properties. In order to obtain some biologically active analogs of these compounds, we developped a synthesis based on the photocyclisation of tertiary $N$-methylated enaminones derived from cyclopentane-1,3-dione and 3 or 6-aminoquinoline. The angular cyclised compounds thus obtained were submitted to Beckmann rearrangement, preceded by the formation of a $Z$ oxime. Finally, the $\delta$-lactame ring was oxidized using $\mathbf{1 0} \%$ palladium/carbon in diphenylether and pyridopyrroloquinolines were obtained. These compounds and the intermediate lactams and cyclopentanopyrroloquinolines were tested in vitro on K 562 cells and A 2780 doxorubicine sensitive and resistant cells. All compounds were less effective than doxorubicine in sensitive cells but their activity wasn't decreased by MDR resistance.

Key words photochemistry; pyridopyrroloquinoline; cytotoxicity; enaminone; Beckmann

The pyridocarbazole alkaloid ellipticine ${ }^{1)} \mathbf{1}$ is well known for its high cytotoxicity against several cancer cell lines due to its intercalating properties and its ability to inhibit DNA religation by topoisomerase II.,3) A number of angular analogs have been prepared in order to obtain more active compounds. For example, one of the most promising products appeared to be intoplicine 2, synthesised firstly by Nguyen et al., ${ }^{4)}$ which acts both as an intercalating agent and as a topoisomerase I and II inhibitor. ${ }^{5,6)}$

So, considering the cytototoxic properties of angular nitrogenous heterocycles, other groups have elaborated several angular tetracyclic compounds derived from two or three nitrogenous heterocycles. Dalla Via et $a l^{7)}$ prepared indolonaphtyridines 3 carrying a dialkylaminoalkyl side chain and different substituents. Linear flow dichroism studies demonstrated these compounds were able to intercalate into DNA and in vitro cytotoxicity studies showed $\mathrm{IC}_{50}$ on HL-60 cells varying between 0.5 and $1.6 \mu \mathrm{M}$. Furthermore, Da Settimo et $\left.a l .{ }^{8}\right)$ prepared several derivatives of purinoquinazoline $\mathbf{4}$, pyridopyrimidopurine and pyridopyrimidobenzimidazole, all of them carrying a dialkylaminoalkyl side chain. Only purinoquinazolines could bind strongly to DNA and therefore could induce DNA double-strand breaks via inhibition of DNA religation by topoisomerase II. These compounds showed $\mathrm{IC}_{50}$ on HL-60 cells varying between 0.072 and $0.47 \mu \mathrm{M}$. Chart 1 represents some of the structures mentionned above.

Therefore, as a part of our studies related to the pharmacochemistry of angular polynitrogenous tetracycles, ${ }^{9,10)}$ we initiated a program in order to examine the synthesis of new pyridopyrroloquinolines and their antitumor activities against resistant cell lines (MDR phenotype +). Our synthetic methodology resides in the use of enaminones $\mathbf{5}$ derived from quinolines and cyclopentane-1,3-dione. Key steps of the synthesis are the photocyclisation of such enaminones followed by Beckmann rearrangement to afford hydroxypyri- dine ring from 2-cyclopent-1-one ring, as shown in Chart 2. In this context, we have previously described the synthesis of indoloquinolines and pyridocarbazoles by photocyclisation of enaminones derived from 3 or 6-aminoquinoline and cyclohexane-1,3-dione. ${ }^{11,12)}$ This present work will allow us to study the photoreactivity of new enaminones and to elaborate potentially cytotoxic compounds.

\section{Results and Discussion}

Chemistry Firstly, we studied the reactivity of secondary halogenated enaminones 12 and 13. As shown in Chart 3, these compounds were obtained in two steps by con-
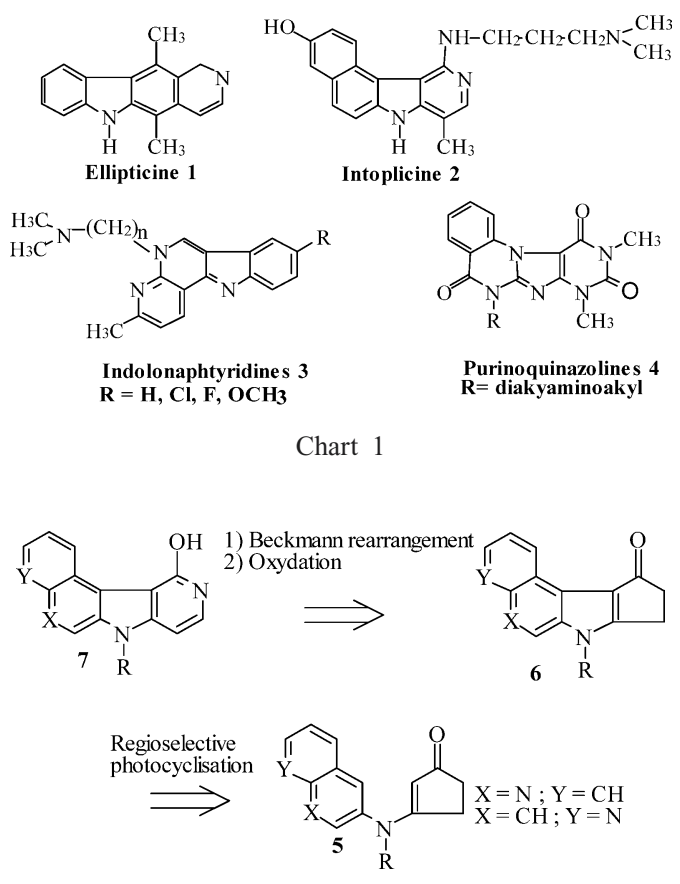

Chart 2 


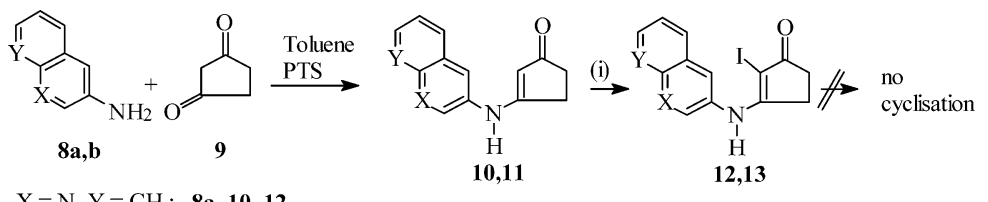

$\mathrm{X}=\mathrm{N}, \mathrm{Y}=\mathrm{CH}: \mathbf{8 a}, \mathbf{1 0}, \mathbf{1 2}$

(i): $\mathrm{BTMAICl}{ }_{2}$, or hu/ $\mathrm{I}_{2} / \mathrm{CH}_{3} \mathrm{CN} /$ with or without $\mathrm{Et}{ }_{3} \mathrm{~N}$

Chart 3

Table 1. Irradiation of Enaminones $\mathbf{1 2}$ and $\mathbf{1 3}$

\begin{tabular}{cllc}
\hline \hline Enaminone & \multicolumn{1}{c}{$\begin{array}{c}\text { Irradiation } \\
\text { conditions }\end{array}$} & Starting material & $\begin{array}{c}\text { Dehalogenated } \\
\text { product }\end{array}$ \\
\hline \multirow{2}{*}{$\mathbf{1 2}$} & $\mathrm{CH}_{3} \mathrm{CN}, \mathrm{Et}_{3} \mathrm{~N}, 4 \mathrm{~h} 00$ & $\mathbf{1 2} ; 0 \%$ & $\mathbf{1 0} ; 80 \%$ \\
& $\mathrm{CH}_{3} \mathrm{CN}, 4 \mathrm{~h} 00$ & $\mathbf{1 2} ; 80 \%$ & $\mathbf{1 0} ; 20 \%$ \\
$\mathbf{1 3}$ & $\mathrm{CH}_{3} \mathrm{CN}, \mathrm{Et}_{3} \mathrm{~N}, 4 \mathrm{~h} 00$ & $\mathbf{1 3} ; 0 \%$ & $\mathbf{1 1} ; 95 \%$ \\
& $\mathrm{CH}_{3} \mathrm{CN}, 4 \mathrm{~h} 00$ & $\mathbf{1 3} ; 100 \%$ & $\mathbf{1 1} ; 0 \%$ \\
\hline
\end{tabular}

Table 2. Irradiation of Enaminones $\mathbf{1 0}$ and $\mathbf{1 1}$

\begin{tabular}{clcc}
\hline \hline Enaminone & \multicolumn{1}{c}{$\begin{array}{c}\text { Irradiation } \\
\text { conditions }\end{array}$} & Starting material & $\begin{array}{c}\text { Halogenated } \\
\text { product }\end{array}$ \\
\hline \multirow{2}{*}{$\mathbf{1 0}$} & $\mathrm{CH}_{3} \mathrm{CN}, \mathrm{I}_{2}, \mathrm{Et}_{3} \mathrm{~N}, 4 \mathrm{~h} 00$ & $\mathbf{1 0} ; 40 \%$ & $\mathbf{1 2} ; 40 \%$ \\
& $\mathrm{CH}_{3} \mathrm{CN}, \mathrm{I}_{2}, 4 \mathrm{~h} 00$ & $\mathbf{1 0} ; 40 \%$ & $\mathbf{1 2} ; 60 \%$ \\
\multirow{2}{*}{$\mathbf{1 1}$} & $\mathrm{CH}_{3} \mathrm{CN}, \mathrm{Et}_{3} \mathrm{~N}, \mathrm{I}_{2}, 4 \mathrm{~h} 00$ & $\mathbf{1 1} ; 20 \%$ & $\mathbf{1 3} ; 80 \%$ \\
& $\mathrm{CH}_{3} \mathrm{CN}, \mathrm{I}_{2}, 4 \mathrm{~h} 00$ & $\mathbf{1 1} ; 0 \%$ & $\mathbf{1 3} ; 100 \%$
\end{tabular}

densation of 3 or 6 -aminoquinoline $(\mathbf{8} \mathbf{a}, \mathbf{b})$ with cyclopentane-1,3-dione in toluene with paratoluenesulfonic acid, followed by $\alpha$-iodination of $\mathbf{1 0}$ and $\mathbf{1 1}$ using BTMAICl${ }_{2}$, according to the procedures previously described. ${ }^{11,13)}$

Irradiation of enaminones $\mathbf{1 2}$ and $\mathbf{1 3}$ in acetonitrile with or without triethylamine gave a mixture of starting product and dehalogenated product, as shown in Table 1 . Contrary to $\alpha$ iodinated enaminones derived from 3 or 6-aminoquinoline and cyclohexane-1,3-dione, no cyclisation occurred. ${ }^{11)}$

Another attempt at photocyclisation was conducted according to the one-pot synthesis of pyridocarbazole and indoloquinoline previously described. ${ }^{11)}$ Compounds $\mathbf{1 0}$ and $\mathbf{1 1}$ were irradiated in acetonitrile $+/-$ triethylamine in presence of iodine ( $2 \mathrm{eq}$ ) for $4 \mathrm{~h}$. But only iodinated products 12 and 13 were obtained without any cyclised products, as shown in Table 2. So, when iodinated enaminones derived from aminoquinolines and cyclopentane-1,3-dione undergo irradiation, the competition between dehalogenation and cyclisation $^{13)}$ is clearly in favour of dehalogenation. As expected, this dehalogenation is enhanced by the presence of triethylamine, particularly in the case of 6-aminoquinoline derivatives. Chart 3 recapitulates these attempts.

Since secondary halogenated enaminones didn't undergo photocyclisation, the reactivity of tertiary enaminones 14 and 15 was investigated (Chart 4). Previous works have been conducted by Gardette $e a{ }^{14}{ }^{14)}$ who cyclised enaminones derived from $N$-methylaniline and cyclopentan-1,3-dione. These compounds were prepared by $N$-methylation of enaminones 10 and 11 using methyl iodide in toluene in presence of sodium hydride. Irradiation of such compounds under different conditions, as shown in Table 3, produced the best yield for cyclised compounds $\mathbf{1 6}$ and $\mathbf{1 7}$ when a mixture toluene/methanol $(95 / 5)$ in a quartz reactor was being used, proving thus that photocyclisation requires much energy. The
Table 3. Irradiation of Enaminones $\mathbf{1 4}$ and $\mathbf{1 5}$

\begin{tabular}{clc}
\hline \hline \multirow{2}{*}{ Enaminone } & \multicolumn{1}{c}{ Irradiation conditions } & Cyclised product \\
\hline \multirow{2}{*}{14} & Pyrex, MeOH, 4h 00 & $\mathbf{1 6} ; 20 \%$ \\
& Pyrex, toluene/MeOH $(50 / 50), 4 \mathrm{~h} 00$ & $\mathbf{1 6} ; 30 \%$ \\
& Pyrex, toluene/MeOH $(95 / 5), 4 \mathrm{~h} 00$ & $\mathbf{1 6} ; 45 \%$ \\
& Quartz, toluene/MeOH $(95 / 5), 4 \mathrm{~h} 00$ & $\mathbf{1 6} ; 50 \%$ \\
& Pyrex, MeOH, 4h 00 & $\mathbf{1 7} ; 5 \%$ \\
& Pyrex, toluene/MeOH $(50 / 50), 4 \mathrm{~h} 00$ & $\mathbf{1 7} ; 5 \%$ \\
& Pyrex, toluene/MeOH $(95 / 5), 4 \mathrm{~h} 00$ & $\mathbf{1 7} ; 15 \%$ \\
& Quartz, toluene/MeOH $(95 / 5), 4 \mathrm{~h} 00$ & $\mathbf{1 7} ; 25 \%$ \\
\hline
\end{tabular}
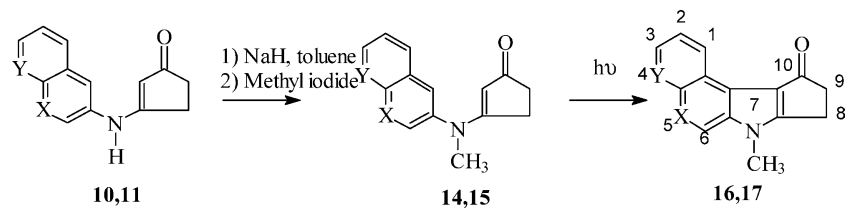

$\mathrm{X}=\mathrm{N}, \mathrm{Y}=\mathrm{CH}: \mathbf{1 0 , 1 4 , 1 6}$

Chart 4

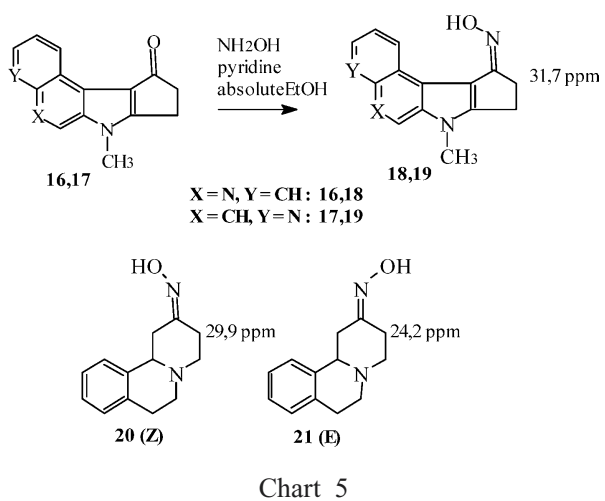

position of the intracyclic nitrogen atom seems to influence the reactivity of these compounds because photocyclisation yield is two fold smaller in the case of compound $\mathbf{1 5}$, derived from 6-aminoquinoline.

This photocyclisation appears to be regioselective, since we obtain only angular derivatives. The angular structure of these compounds is proven by the multiplet corresponding to $\mathrm{H} 1$, and whose shift in ${ }^{1} \mathrm{H}-\mathrm{NMR}$ spectrum appears at $8.77 \mathrm{ppm}$ for compound $\mathbf{1 6}$ and $9.17 \mathrm{ppm}$ for compound $\mathbf{1 7}$, due to the deshielding effect of the carbonyl group. Besides, compound $\mathbf{1 6}$ shows a characteristic singlet corresponding to $\mathrm{H} 6$ at $8.76 \mathrm{ppm}$ and compound $\mathbf{1 7}$ shows a characteristic $\mathrm{AB}$ system corresponding to $\mathrm{H} 5$ and $\mathrm{H} 6$ at $7.57 \mathrm{ppm}$.

Thus, the cyclopentenone ring has been modified in three steps including Beckmann rearrrangement in order both to introduce a third nitrogen atom and to obtain some totally aromatised compounds which can theoretically better inter- 
calate into DNA.

First of all, the compounds $\mathbf{1 6}$ and $\mathbf{1 7}$ were treated by hydroxylamine hydrochloride, following the procedure described by Sekar et al. ${ }^{15)}$ and $\mathrm{Z}$ oximes 18 and 19 were obtained. Configuration of $\mathrm{C}=\mathrm{N}$ bond was determined by considering the ${ }^{13} \mathrm{C}$-NMR shift of the secondary carbon adjacent to the oxime function in our structures and in close compounds 20 and 21 synthetised by Scheiber et al., ${ }^{16)}$ as shown in Chart 5.

The second step of this ring modification consisted in regioselective Beckmann rearrangement ${ }^{17}$ ) using polyphosphoric acid PPA, which gave lactams 22 (30\%) and 23 $(60 \%)$. The structure of the lactams was deduced from the configuration of the oximes, considering the mechanism of Beckmann transposition, and was confirmed by considering the ${ }^{13} \mathrm{C}$-NMR shift of the secondary carbon adjacent to the amide function in our structures and in close compounds $\mathbf{2 4}$ and 25 synthetised by Scheiber et al., ${ }^{16)}$ as shown in Chart 6.

In order to obtain compounds $\mathbf{2 2}$ and $\mathbf{2 3}$ with better yields, compounds $\mathbf{1 6}$ and $\mathbf{1 7}$ were submitted to Schmidt transposition $^{17)}$ using sodium azide in refluxing sulfuric acid. But after $3 \mathrm{~h}$, the starting material was recovered unchanged.

Finally, compounds $\mathbf{2 2}$ and $\mathbf{2 3}$ were treated by palladium/carbon $10 \%$ in diphenylether ${ }^{18)}$ and underwent $\mathrm{C}_{8}-\mathrm{C}_{9}$ bond oxydation to give the pyridopyrroloquinolines $\mathbf{2 6}$ and 27 with $30 \%$ and $32 \%$ yield respectively, as shown in Chart 7. This oxydation was expected to be more successful than previous attempts to oxydize cyclohexenone ring, since lactime tautomer in $\delta$-lactam ring is probably more easely formed than enol tautomer in cyclohexenone ring.

Biological Results In continuation of our previous works $^{9,10)}$ concerning the antiproliferative activity of tetracyclic nitrogenous heterocycles, and more precisely, their activity against $\mathrm{MDR}^{+}$cancer cells lines, the cytotoxicity of the compounds 16, 17, 22, 23, 26 and 27 was evaluated by a cell

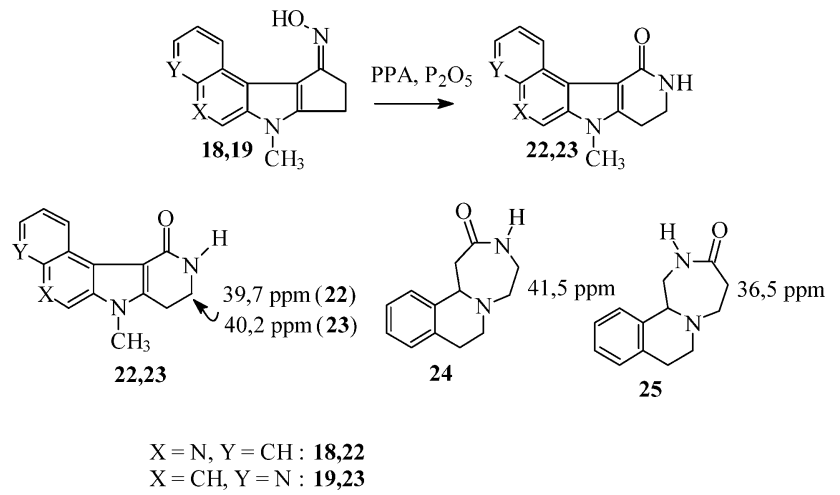

Chart 6 growth inhibition assay against two human cell lines: K 562 (leukemia), and A 2780 (ovarian cancer) doxorubicine-sensitive and resistant $\left(\mathrm{MDR}^{+}\right)$and was compared to the cytotoxicity of doxorubicine. The resistant subline A 2780 R was established by the continuous exposure of cells to gradually increasing concentrations of doxorubicine. The resistant subline K 562 R wasn't tested because of the poor activity of our products against $\mathrm{K} 562 \mathrm{~S}$ cells. $\mathrm{IC}_{50}$ (concentration inhibiting $50 \%$ of the cell proliferation) expressed in $\mathrm{mol} / 1$ and resistance factor $\left(\mathrm{IC}_{50}\right.$ on $\mathrm{A} 2780$ resistant cells/ $\mathrm{IC}_{50}$ on $\mathrm{A} 2780$ sensitive cells) of each compound are recapitulated in Table 4. $\mathrm{IC}_{50}$ of compound 22 couldn't be determined exactly because of its poor solubility in the culture medium.

All the compounds were less effective than doxorubicine in all sensitive cells, whereas compounds 17, 23, 26 and 27 were as active as doxorubicine on A 2780 resistant cells with $\mathrm{IC}_{50}$ varying between 5 and $9.8 \times 10^{-6} \mathrm{~mol} / \mathrm{l}$. The resistance factor of all those compounds (except 22, not determined) varies between 1.1 and 6.1 (doxorubicine: 121), which indicates that these compounds are not concerned by the multidrug resistance phenomenon.

Among these compounds, the less active ones are those which possess $\delta$-lactam ring. This can be due either to the poor solubility of these structures in the culture medium or to the structure of the compound itself. Besides, compounds derived from 6-aminoquinoline are globally more active than compounds derived from 3-aminoquinoline, proving the importance of the quinolinic nitrogen position in biological activity. But there's only a little difference between the compounds 16 and 17 carring a cyclopentenone ring and the compounds 26 and 27 carrying an hydroxypyridine ring.

Compounds 16, 17, 26 and 27, which show the lowest $\mathrm{IC}_{50}$, are good candidates for further in vivo studies.

\section{Conclusion}

In this paper, we have reported the synthesis of tetracyclic nitrogen heterocycles: pyrido pyrroloquinolines obtained from cyclopentanopyrroloquinolines via a Beckmann rearrangement. The photochemical step which gives cyclopentanopyrroloquinolines from enaminones occured with a total regioselectivity, since only angular compounds are obtained. The first in vitro studies reveal that the main interest of these

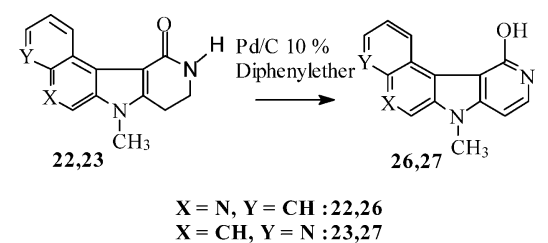

Chart 7

Table 4. $\mathrm{IC}_{50}$ and Resistance Factor of Tested Compounds and Doxorubicine

\begin{tabular}{|c|c|c|c|c|}
\hline Compounds & K 562 cells (mol/1) & A 2780 cells sensitive $(\mathrm{mol} / \mathrm{l})$ & A 2780 cells resistant $(\mathrm{mol} / \mathrm{l})$ & Resistance factor \\
\hline 16 & $4.9 \times 10^{-5} \pm 1.1 \times 10^{-5}$ & $3.3 \times 10^{-5} \pm 2.5 \times 10^{-5}$ & $8.8 \times 10^{-5} \pm 5.4 \times 10^{-5}$ & 2.6 \\
\hline 17 & $5.8 \times 10^{-5} \pm 1.2 \times 10^{-5}$ & $2.7 \times 10^{-6} \pm 1.5 \times 10^{-6}$ & $6.3 \times 10^{-6} \pm 5.6 \times 10^{-7}$ & 2.3 \\
\hline 22 & $>4.2 \times 10^{-4}$ & $>4.2 \times 10^{-4}$ & $>4.2 \times 10^{-4}$ & n.d. \\
\hline 23 & $7.7 \times 10^{-5} \pm 1.9 \times 10^{-5}$ & $1.6 \times 10^{-5} \pm 7 \times 10^{-6}$ & $9.8 \times 10^{-6} \pm 9.4 \times 10^{-7}$ & 6.1 \\
\hline 26 & $5 \times 10^{-5} \pm 1 \times 10^{-5}$ & $4.5 \times 10^{-6} \pm 1 \times 10^{-7}$ & $5 \times 10^{-6} \pm 6 \times 10^{-7}$ & 1.1 \\
\hline 27 & $1.1 \times 10^{-5} \pm 8.3 \times 10^{-6}$ & $5.7 \times 10^{-6} \pm 7 \times 10^{-7}$ & $8.5 \times 10^{-6} \pm 3.8 \times 10^{-7}$ & 1.5 \\
\hline Doxorubicine & $1.6 \times 10^{-7} \pm 3.3 \times 10^{-8}$ & $2.4 \times 10^{-8} \pm 4 \times 10^{-9}$ & $2.9 \times 10^{-6} \pm 4.9 \times 10^{-7}$ & 121 \\
\hline
\end{tabular}


compounds resides in their activity toward resistant cells. Further studies on the pharmacomodulation of such compounds are now in progress and should lead to an interesting class of new potential anticancer agents with no multidrug resistance phenomena.

\section{Experimental}

IR spectra were recorded with a Perkin-Elmer 377 spectrophotometer. Absorption bands are expressed in centimeters $\left(\mathrm{cm}^{-1}\right)$ using polystyrene calibration and only noteworthy absorptions are listed. ${ }^{1} \mathrm{H}$ - and ${ }^{13} \mathrm{C}-\mathrm{NMR}$ spectra were recorded on a Brüker AC 100 or EM 400 WB. Chemical shift data are reported in ppm downfield $\delta$ from TMS. Coupling constants $J$ are given in Hz. s, d, dd, t, and m mean respectively singlet, doublet, double doublet, triplet, and multiplet. Mass spectrometry was done on a LKB 2091 instrument at $15 \mathrm{eV}$. Melting points were determined on a Buchi capillary melting point apparatus and are not corrected. Elemental analysis was performed by Microanalytical center, ENSCM, Montpellier.

Irradiations were conducted in a pyrex or a quartz well apparatus using a medium pressure mercury UV lamp (Heraeus TQ 150). Total volume of solvent(s) was about $350-400 \mathrm{ml}$. In order to remove oxygen, the reaction mixture was submitted to ultrasound waves for $10 \mathrm{~min}$ before irradiation. Besides, during the irradiation, the reaction mixture was flushed with a stream of nitrogen. Triethylamine $(4 \mathrm{ml})$ or molecular iodine $(500 \mathrm{mg}$, $1.97 \mathrm{mmol}$ ) could be added to the reaction mixture.

3-[3'-Quinolinylamino]cyclopent-2-en-1-one 10 A solution of 3aminoquinoline $(3 \mathrm{~g}, 21 \mathrm{mmol}), 1.3$ cyclohexanedione $(2.2 \mathrm{~g}, 22 \mathrm{mmol})$ and paratoluenesulfonic acid $(500 \mathrm{mg}, 2.9 \mathrm{mmol})$ in $50 \mathrm{ml}$ of anhydrous toluene was refluxed under nitrogen in a Dean-Stark apparatus for $6 \mathrm{~h}$. After cooling, the solution was washed with water and extracted with dichloromethane. Organic layers were dried over sodium sulfate and evaporated in vacuo. The crude product was chromatographed on alumina gel using dichloromethane and a gradient of methanol as eluent to give $\mathbf{1 0}$ as a yellow powder: $40 \%$, mp: $130-132{ }^{\circ} \mathrm{C} .{ }^{1} \mathrm{H}-\mathrm{NMR}\left(\mathrm{CDCl}_{3}, 100 \mathrm{MHz}\right) \delta$ : $2.44(2 \mathrm{H}, \mathrm{m}, \mathrm{H} 5), 2.80(2 \mathrm{H}, \mathrm{m}, \mathrm{H} 4), 5.68(1 \mathrm{H}, \mathrm{s}, \mathrm{H} 2), 7.62\left(3 \mathrm{H}, \mathrm{m}, \mathrm{H}^{\prime}, \mathrm{H}^{\prime}\right.$ and $\left.\mathrm{H}^{\prime}\right), 7.90\left(2 \mathrm{H}, \mathrm{m}, \mathrm{H} 4^{\prime}\right.$ and $\left.\mathrm{H} 8^{\prime}\right), 8.57\left(1 \mathrm{H}, \mathrm{d}, J=2.2 \mathrm{~Hz}, \mathrm{H} 2^{\prime}\right) ;{ }^{13} \mathrm{C}-$ NMR $\left(\mathrm{CDCl}_{3}, 100 \mathrm{MHz}\right) \delta: 29.19,33.41,102.86,124.88,127.78,128.14$, 128.47 (2C), 129.28, 134.21, 144.73, 145.39, 174.58, 208.34. Anal. Calcd for $\mathrm{C}_{14} \mathrm{H}_{12} \mathrm{~N}_{2} \mathrm{O}$ : C, 75.0; H, 5.36; N, 12.50. Found: C, 74.96; H, 5.32; N, 12.39

3-[6'-Quinolinylamino]cyclopent-2-en-1-one 11 This compound was obtained in $25 \%$ yield according to the procedure described for compound 10. White powder, mp: $134-136{ }^{\circ} \mathrm{C} .{ }^{1} \mathrm{H}-\mathrm{NMR}\left(\mathrm{CDCl}_{3}, 100 \mathrm{MHz}\right) \delta: 2.39$ $(2 \mathrm{H}, \mathrm{m}, \mathrm{H} 5), 2.76(2 \mathrm{H}, \mathrm{m}, \mathrm{H} 4), 5.67(1 \mathrm{H}, \mathrm{s}, \mathrm{H} 2), 7.31\left(2 \mathrm{H}, \mathrm{m}, \mathrm{H} 7^{\prime}\right.$ and $\left.\mathrm{H} 3^{\prime}\right)$, $7.49\left(1 \mathrm{H}, \mathrm{s}, \mathrm{H} 5^{\prime}\right), 7.98\left(2 \mathrm{H}, \mathrm{m}, \mathrm{H} 4^{\prime}\right.$ and $\left.\mathrm{H} 8^{\prime}\right), 8.69\left(1 \mathrm{H}, \mathrm{m}, \mathrm{H} 2{ }^{\prime}\right) ;{ }^{13} \mathrm{C}-\mathrm{NMR}$ $\left(\mathrm{CDCl}_{3}, 100 \mathrm{MHz}\right) \delta: 29.3,33.4,102.8,116.8,122.2,124.9,129.2,130.0$, 136.5, 138.6, 145.1, 149.4, 174.2, 208.1. Anal. Calcd for $\mathrm{C}_{14} \mathrm{H}_{12} \mathrm{~N}_{2} \mathrm{O}$ : C, $75.0 ; \mathrm{H}, 5.36 ; \mathrm{N}, 12.50$. Found: C, 75.04; H, 5.48; N, 12.42

2-Iodo-3-[3'-quinolinylamino|cyclopent-2-en-1-one 12 A solution of enaminone $10(250 \mathrm{mg}, 1.1 \mathrm{mmol})$, benzyltrimethylammonium dichloroiodate BTMAICl $_{2}(390 \mathrm{mg}, 1.1 \mathrm{mmol})$ and sodium bicarbonate $(660 \mathrm{mg}$, $7.7 \mathrm{mmol}$ ) in $40 \mathrm{ml}$ of anhydrous dichloromethane and $20 \mathrm{ml}$ of anhydrous methanol was stirred under nitrogen at room temperature for $1 \mathrm{~h}$. The solution was filtered to eliminate sodium bicarbonate and the solvents were evaporated in vacuo. The residue was dissolved in dichloromethane and washed with water. The organic layer was dried over sodium sulfate and evaporated in vacuo. The crude product was chromatographed on alumina gel using dichloromethane and a gradient of methanol as eluent to give $\mathbf{1 2}$ as a yellow powder: $80 \%, \mathrm{mp}: 104-106^{\circ} \mathrm{C} .{ }^{1} \mathrm{H}-\mathrm{NMR}\left(\mathrm{CDCl}_{3}, 100 \mathrm{MHz}\right) \delta$ : $2.53(2 \mathrm{H}, \mathrm{m}, \mathrm{H} 5), 2.82(2 \mathrm{H}, \mathrm{m}, \mathrm{H} 4), 7.53\left(1 \mathrm{H}, \mathrm{m}, \mathrm{H} 7^{\prime}\right), 7.67\left(1 \mathrm{H}, \mathrm{m}, \mathrm{H} 6^{\prime}\right)$, $7.76\left(1 \mathrm{H}, \mathrm{d}, J=8.1 \mathrm{~Hz}, \mathrm{H} 5^{\prime}\right), 7.99\left(2 \mathrm{H}, \mathrm{m}, \mathrm{H} 4^{\prime}\right.$ and $\left.\mathrm{H} 8^{\prime}\right), 8.70(1 \mathrm{H}, \mathrm{d}$, $\left.J=2.5 \mathrm{~Hz}, \mathrm{H} 2{ }^{\prime}\right) ;{ }^{13} \mathrm{C}-\mathrm{NMR}\left(\mathrm{CDCl}_{3}, 100 \mathrm{MHz}\right) \delta: 29.1,32.6,70.7,128.3$ (2C), 128.7 (2C), 129.1 130.6, 130.7, 146.2, 147.8, 175.5, 200.6. Anal. Calcd for $\mathrm{C}_{14} \mathrm{H}_{11} \mathrm{IN}_{2} \mathrm{O}$ : C, 48.0; H, 3.14; N, 8.0. Found: C, 47.88; H, 3.17; N, 7.96.

2-Iodo-3-[6'-quinolinylamino]cyclopent-2-en-1-one 13 This compound was obtained in $80 \%$ yield according to the procedure described for compound 12. Yellow powder, $\mathrm{mp}: 110-112^{\circ} \mathrm{C} .{ }^{1} \mathrm{H}-\mathrm{NMR}\left(\mathrm{CDCl}_{3}\right.$, $100 \mathrm{MHz}) \delta: 2.62(2 \mathrm{H}, \mathrm{m}, \mathrm{H} 5), 2.96(2 \mathrm{H}, \mathrm{m}, \mathrm{H} 4), 7.46\left(1 \mathrm{H}, \mathrm{m}, \mathrm{H} 3^{\prime}\right), 7.57$ $\left(1 \mathrm{H}, \mathrm{d}, J=6.5 \mathrm{~Hz}, \mathrm{H}^{\prime}\right), 7.65\left(1 \mathrm{H}, \mathrm{s}, \mathrm{H} 5^{\prime}\right), 8.1\left(1 \mathrm{H}, \mathrm{d}, J=4.4 \mathrm{~Hz}, \mathrm{H} 4^{\prime}\right), 8.16$ $\left(1 \mathrm{H}, \mathrm{d}, J=8.2 \mathrm{~Hz}, \mathrm{H} 8^{\prime}\right), 8.85\left(1 \mathrm{H}, \mathrm{d}, J=3.0 \mathrm{~Hz}, \mathrm{H} 2{ }^{\prime}\right) ;{ }^{13} \mathrm{C}-\mathrm{NMR}\left(\mathrm{CDCl}_{3}\right.$, $100 \mathrm{MHz}) \delta: 28.8,32.6,70.9,121.1,122.6,126.9,129.0,130.9,136.2$, 136.7, 146.1, 150.6, 174.7, 199.8. Anal. Calcd for $\mathrm{C}_{14} \mathrm{H}_{11} \mathrm{IN}_{2} \mathrm{O}: \mathrm{C}, 48.0 ; \mathrm{H}$, $3.14 ;$ N, 8.0. Found: C, 47.97; H, 3.25; N, 8.11.
3-[(3'-Quinolinyl)methylamino|cyclopent-2-en-1-one 14 Compound $10(600 \mathrm{mg}, 2.7 \mathrm{mmol})$ was added to a suspension of sodium hydride $(1 \mathrm{~g}$, $25 \mathrm{mmol}, 60 \%$ in mineral oil) in anhydrous toluene $(50 \mathrm{ml})$. The mixture was refluxed under nitrogen for $2 \mathrm{~h}$ and cooled to room temperature. Methyl iodide $(5 \mathrm{ml}, 80 \mathrm{mmol})$ was then added and the mixture was refluxed for $4 \mathrm{~h}$. After cooling, toluene was washed with water and the insoluble residue in the balloon flask was dissolved in dichloromethane and also washed with water. The organic layers were dried over sodium sulfate and evaporated in vacuo. The crude product was chromatographed on alumina gel with dichloromethane and a gradient of methanol as eluent to give $\mathbf{1 4}$ as a yellow oil: $60 \%$. ${ }^{1} \mathrm{H}-\mathrm{NMR}\left(\mathrm{CDCl}_{3}, 100 \mathrm{MHz}\right) \delta: 2.36(2 \mathrm{H}, \mathrm{m}, \mathrm{H} 5), 2.50(2 \mathrm{H}, \mathrm{m}$, $\mathrm{H} 4), 3.41\left(3 \mathrm{H}, \mathrm{s}, \mathrm{CH}_{3}\right), 5.16(1 \mathrm{H}, \mathrm{s}, \mathrm{H} 2), 7.56\left(1 \mathrm{H}, \mathrm{m}, \mathrm{H}^{\prime}\right), 7.71(1 \mathrm{H}, \mathrm{m}$, $\left.\mathrm{H} 6^{\prime}\right), 7.78\left(1 \mathrm{H}, \mathrm{d}, J=8.1 \mathrm{~Hz}, \mathrm{H} 5^{\prime}\right), 7.99\left(1 \mathrm{H}, \mathrm{d}, J=2.4 \mathrm{~Hz}, \mathrm{H} 4^{\prime}\right), 8.07(1 \mathrm{H}, \mathrm{d}$, $\left.J=8.4 \mathrm{~Hz}, \mathrm{H} 8^{\prime}\right), 8.76\left(1 \mathrm{H}, \mathrm{d}, J=2.5 \mathrm{~Hz}, \mathrm{H} 2^{\prime}\right) ;{ }^{13} \mathrm{C}-\mathrm{NMR}\left(\mathrm{CDCl}_{3}, 100 \mathrm{MHz}\right)$ $\delta: 28.8,34.8,41.8,103.9,128.1,128.1,128.1,129.7,130.5,132.4,138.5$, 147.1, 149.1, 177.3, 204.7. Anal. Calcd for $\mathrm{C}_{15} \mathrm{H}_{14} \mathrm{~N}_{2} \mathrm{O}$ : C, 75.63; H, 5.88; N, 11.76. Found: C, 75.75; H, 5.82; N, 11.81 .

3-[(6'-Quinolinyl)methylamino]cyclopent-2-en-1-one 15 This compound was obtained in $60 \%$ yield according to the procedure described for compound 14. Yellow oil. ${ }^{1} \mathrm{H}-\mathrm{NMR}\left(\mathrm{CDCl}_{3}, 100 \mathrm{MHz}\right) \delta: 2.41(2 \mathrm{H}, \mathrm{m}, \mathrm{H} 5)$, $2.56(2 \mathrm{H}, \mathrm{m}, \mathrm{H} 4), 3.44\left(3 \mathrm{H}, \mathrm{s}, \mathrm{CH}_{3}\right), 5.21(1 \mathrm{H}, \mathrm{s}, \mathrm{H} 2), 7.46\left(1 \mathrm{H}, \mathrm{m}, \mathrm{H} 3^{\prime}\right)$ $7.57\left(1 \mathrm{H}, \mathrm{d}, J=6.5 \mathrm{~Hz}, \mathrm{H} 7^{\prime}\right), 7.67\left(1 \mathrm{H}, \mathrm{s}, \mathrm{H} 5^{\prime}\right), 8.15\left(2 \mathrm{H}, \mathrm{m}, \mathrm{H} 4^{\prime}\right.$ and $\left.\mathrm{H} 8^{\prime}\right)$, $8.95\left(1 \mathrm{H}, \mathrm{d}, J=2.6 \mathrm{~Hz}, \mathrm{H} 2^{\prime}\right) ;{ }^{13} \mathrm{C}-\mathrm{NMR}\left(\mathrm{CDCl}_{3}, 100 \mathrm{MHz}\right) \delta: 30.1,34.6$, 41.7, 103.6, 122.4, 124.6, 128.2, 128.8, 131.8, 136.3, 143.1, 147.3, 151.5, 177.3, 204.7. Anal. Calcd for $\mathrm{C}_{15} \mathrm{H}_{14} \mathrm{~N}_{2} \mathrm{O}: \mathrm{C}, 75.63 ; \mathrm{H}, 5.88 ; \mathrm{N}, 11.76$. Found: C, 75.60; H, 5.81; N, 11.72 .

7-Methyl-10-oxocyclopentano[4,5]pyrrolo[2,3-c]quinoline 16 Compound $14(500 \mathrm{mg}, 2.1 \mathrm{mmol})$ underwent irradiation under different conditions (see Table 3 ). Then, the solvents were evaporated under reduced pressure. The crude product was chromatographed on alumina gel using dichloromethane as eluent to give $\mathbf{1 6}$ as a white powder: $50 \%$ (best yield), mp: $213-215^{\circ} \mathrm{C} .{ }^{1} \mathrm{H}-\mathrm{NMR}\left(\mathrm{CDCl}_{3}, 100 \mathrm{MHz}\right) \delta: 2.86(2 \mathrm{H}, \mathrm{m}, \mathrm{H} 9), 2.95$ $(2 \mathrm{H}, \mathrm{m}, \mathrm{H} 8), 3.63\left(3 \mathrm{H}, \mathrm{s}, \mathrm{CH}_{3}\right), 7.60(2 \mathrm{H}, \mathrm{m}, \mathrm{H} 2$ and $\mathrm{H} 3), 8.10(1 \mathrm{H}, \mathrm{m}, \mathrm{H} 4)$, $8.76(2 \mathrm{H}, \mathrm{m}, \mathrm{H} 1$ and $\mathrm{H} 6) ;{ }^{13} \mathrm{C}-\mathrm{NMR}\left(\mathrm{CDCl}_{3}, 100 \mathrm{MHz}\right) \delta: 20.1,31.4,41.3$, 121.1, 123.3, 124.2, 127.2, 127.6, 128.2, 129.1, 135.5, 135.6, 143.7, 167.9, 195.3. IR $\mathrm{cm}^{-1}=v_{\mathrm{C}=\mathrm{O}}=1674$. Anal. Calcd for $\mathrm{C}_{15} \mathrm{H}_{12} \mathrm{~N}_{2} \mathrm{O}: \mathrm{C}, 76.27 ; \mathrm{H}$, 5.08; N, 11.86. Found: C, 76.16; H, 5.11; N, 11.91

7-Methyl-10-oxocyclopentano[4,5]pyrrolo[3,2- $f$ ]quinoline 17 This compound was obtained in $25 \%$ yield (best yield) according to the procedure described for compound 16. White powder, mp: $206-208^{\circ} \mathrm{C} .{ }^{1} \mathrm{H}-$ NMR $\left(\mathrm{CDCl}_{3}, 100 \mathrm{MHz}\right) \delta: 2.71(2 \mathrm{H}, \mathrm{m}, \mathrm{H} 9), 2.81(2 \mathrm{H}, \mathrm{m}, \mathrm{H} 8), 3.42(3 \mathrm{H}$, s, $\left.\mathrm{CH}_{3}\right), 7.36(1 \mathrm{H}, \mathrm{d}, J=9.1 \mathrm{~Hz}, \mathrm{H} 6), 7.41(1 \mathrm{H}, \mathrm{m}, \mathrm{H} 2), 7.78(1 \mathrm{H}, \mathrm{d}$, $J=9.1 \mathrm{~Hz}, \mathrm{H} 5), 8.79(1 \mathrm{H}, \mathrm{s}, \mathrm{H} 3), 9.17(1 \mathrm{H}, \mathrm{dd}, J=7.1,1.22 \mathrm{~Hz}, \mathrm{H1}) ;{ }^{13} \mathrm{C}-$ NMR $\left(\mathrm{CDCl}_{3}, 100 \mathrm{MHz}\right) \delta: 21.3,31.2,41.4,114.7,119.9,121.7,121.8$, $123.8,125.8,136.1,139.3,145.8,149.2,166.5,195.7 . \quad \mathrm{IR} \mathrm{cm}^{-1}=$ $v_{\mathrm{C}=\mathrm{O}}=1667$. Anal. Calcd for $\mathrm{C}_{15} \mathrm{H}_{12} \mathrm{~N}_{2} \mathrm{O}: \mathrm{C}, 76.27 ; \mathrm{H}, 5.08 ; \mathrm{N}, 11.86$. Found: C, 76.32; H, 5.06; N, 11.80 .

10-Hydroxyimino-7-methyl-cyclopentano[4,5]pyrrolo[2,3-c]quinoline 18 Compound $16(180 \mathrm{mg}, 0.76 \mathrm{mmol})$ and hydroxylamine hydrochloride $(1 \mathrm{~g}, 14.4 \mathrm{mmol})$ were dissolved in absolute ethanol $(15 \mathrm{ml})$ and $2 \mathrm{ml}$ of pyridine were added. The reaction mixture was refluxed under nitrogen for $3 \mathrm{~h}$. After cooling, $30 \mathrm{ml}$ of an aqueous solution of sodium carbonate $10 \%$ were added. After extraction with dichloromethane, the organic layers were dried over sodium sulfate and evaporated in vacuo. The crude product was chromatographed on silica gel using dichloromethane and a gradient of methanol as eluent to give 18 as a white powder: $30 \%, \mathrm{mp}$ : $154-156{ }^{\circ} \mathrm{C} .{ }^{1} \mathrm{H}-\mathrm{NMR}$ $\left(\mathrm{CDCl}_{3}, 400 \mathrm{MHz}\right) \delta: 2.99(2 \mathrm{H}, \mathrm{m}, \mathrm{H} 9), 3.32(2 \mathrm{H}, \mathrm{m}, \mathrm{H} 8), 3.81(3 \mathrm{H}, \mathrm{s}$, $\left.\mathrm{CH}_{3}\right), 7.52(2 \mathrm{H}, \mathrm{m}, \mathrm{H} 2$ and $\mathrm{H} 3), 8.0(1 \mathrm{H}, \mathrm{d}, J=8.0 \mathrm{~Hz}, \mathrm{H} 4), 8.78(1 \mathrm{H}, \mathrm{s}$, $\mathrm{H} 6), 8.98(1 \mathrm{H}, \mathrm{d}, J=8.0 \mathrm{~Hz}, \mathrm{H} 1) ;{ }^{13} \mathrm{C}-\mathrm{NMR}\left(\mathrm{CDCl}_{3}, 400 \mathrm{MHz}\right) \delta: 22.6$, $31.2,31.7,116.9,123.7,123.7,126.5,127.4,127.5,128.2,135.1,135.6$, 143.2, 158.0, 158.3. IR $\mathrm{cm}^{-1}=v_{\mathrm{C}=\mathrm{N}}=1584, v_{\mathrm{O}-\mathrm{H}}=2400-3600, \mathrm{MS}=252$ (35\%), $251(20 \%), 154(100 \%), 136(80 \%)$. Anal. Calcd for $\mathrm{C}_{15} \mathrm{H}_{13} \mathrm{~N}_{3} \mathrm{O}: \mathrm{C}$, 71.71; H, 5.18; N, 16.73. Found: C, 71.83; H, 5.21; N, 16.67.

10-Hydroxyimino-7-methyl-cyclopentano[4,5]pyrrolo[3,2-f]quinoline 19 This compound was obtained in 33\% yield according to the procedure described for compound 18. White powder, mp: $155-157^{\circ} \mathrm{C} .{ }^{1} \mathrm{H}-\mathrm{NMR}$ $\left(\mathrm{CDCl}_{3}, 400 \mathrm{MHz}\right) \delta: 3.09(2 \mathrm{H}, \mathrm{m}, \mathrm{H} 9), 3.27(2 \mathrm{H}, \mathrm{m}, \mathrm{H} 8), 3.85(3 \mathrm{H}, \mathrm{s}$, $\left.\mathrm{CH}_{3}\right), 7.75(1 \mathrm{H}, \mathrm{d}, J=9.1 \mathrm{~Hz}, \mathrm{H} 6), 7.85(1 \mathrm{H}, \mathrm{m}, \mathrm{H} 2), 8.15(1 \mathrm{H}, \mathrm{d}, J=9.1 \mathrm{~Hz}$, $\mathrm{H} 5), 8.85(1 \mathrm{H}, \mathrm{d}, J=5.4 \mathrm{~Hz}, \mathrm{H} 3), 10.07(1 \mathrm{H}, \mathrm{d}, J=8.3 \mathrm{~Hz}, \mathrm{H} 1) ;{ }^{13} \mathrm{C}-\mathrm{NMR}$ $\left(\mathrm{CDCl}_{3}, 400 \mathrm{MHz}\right) \delta: 24.2,31.5,31.7,113.9,117.3,118.6,121.3,121.8$, $125.6,136.6,139.9,141.7,145.8,158.1,159.01 . \mathrm{IR} \mathrm{cm}^{-1}=v_{\mathrm{C}=\mathrm{N}}=1586$, $v_{\mathrm{O}-\mathrm{H}}=2400-3600, \mathrm{MS}=252(5 \%), 250(6 \%), 154(40 \%), 149(100 \%), 136$ (40\%). Anal. Calcd for $\mathrm{C}_{15} \mathrm{H}_{13} \mathrm{~N}_{3} \mathrm{O}: \mathrm{C}, 71.71 ; \mathrm{H}, 5.18 ; \mathrm{N}, 16.73$. Found: $\mathrm{C}$, 71.63; H, 5.20; N, 16.69 . 
8,9-Dihydro-7-methyl-11-oxopyrido $\left[3^{\prime}, 4^{\prime}-4,5\right]$ pyrrolo[2,3-c]quinoline 22 Compound $18(80 \mathrm{mg}, 0.32 \mathrm{mmol})$ was added to polyphosphoric acid PPA $(3 \mathrm{~g})$ and phosphorus pentoxide $(2 \mathrm{~g})$ and the reaction mixture was stirred at $130^{\circ} \mathrm{C}$ for $1 \mathrm{~h}$. After cooling, $100 \mathrm{ml}$ of ice cooled water were added. Then, sodium carbonate was added until $\mathrm{pH}$ became 7. After extraction with dichloromethane, the organic layers were dried over sodium sulfate and evaporated in vacuo. The crude product was chromatographed on silica gel using dichloromethane and a gradient of methanol as eluent to give $\mathbf{2 2}$ as a white powder: $30 \%, \mathrm{mp}: 184-186{ }^{\circ} \mathrm{C} .{ }^{1} \mathrm{H}-\mathrm{NMR}\left(\mathrm{CDCl}_{3}, 400 \mathrm{MHz}\right) \delta$ : $3.37(2 \mathrm{H}, \mathrm{t}, J=7.0 \mathrm{~Hz}, \mathrm{H} 8), 3.94(2 \mathrm{H}, \mathrm{t}, J=7.0 \mathrm{~Hz}, \mathrm{H} 9), 4.14\left(3 \mathrm{H}, \mathrm{s}, \mathrm{CH}_{3}\right)$, $7.97(2 \mathrm{H}, \mathrm{m}, \mathrm{H} 2$ and $\mathrm{H} 3), 8.23(1 \mathrm{H}, \mathrm{d}, J=8.1 \mathrm{~Hz}, \mathrm{H} 4), 9.50(1 \mathrm{H}, \mathrm{s}, \mathrm{H} 6), 9.78$ $(1 \mathrm{H}, \mathrm{d}, J=8.4 \mathrm{~Hz}, \mathrm{H1}) ;{ }^{13} \mathrm{C}-\mathrm{NMR}\left(\mathrm{CDCl}_{3}, 400 \mathrm{MHz}\right) \delta: 22.3,32.1,39.7$, $109.02,120.8,122.3,129.6,129.9,130.0$ (2C), 132.4, 133.5, 134.2, 156.1, 167.0. IR cm $\mathrm{cm}^{-1}=v_{\mathrm{C}=\mathrm{O}}=1645, \mathrm{MS}=252(18 \%), 154(96 \%), 136(100 \%)$. Anal. Calcd for $\mathrm{C}_{15} \mathrm{H}_{13} \mathrm{~N}_{3} \mathrm{O}: \mathrm{C}, 71.71 ; \mathrm{H}, 5.18 ; \mathrm{N}, 16.73$. Found: $\mathrm{C}, 71.79 ; \mathrm{H}$, $5.22 ; \mathrm{N}, 16.79$.

8,9-Dihydro-7-methyl-11-oxo-pyrido[3', 4' $^{\prime}$-4,5]pyrrolo[3,2-f $]$ quinoline 23 This compound was obtained in $60 \%$ yield according to the procedure described for compound 22. White powder, mp: $198-200{ }^{\circ} \mathrm{C}$. ${ }^{1} \mathrm{H}-\mathrm{NMR}$ $\left(\mathrm{CDCl}_{3}, 400 \mathrm{MHz}\right) \delta: 3.29(2 \mathrm{H}, \mathrm{t}, J=7.1 \mathrm{~Hz}, \mathrm{H} 8), 3.89(2 \mathrm{H}, \mathrm{t}, J=7.1 \mathrm{~Hz}$, H9), $4.02\left(3 \mathrm{H}, \mathrm{s}, \mathrm{CH}_{3}\right), 7.98(1 \mathrm{H}, \mathrm{m}, \mathrm{H} 2), 8.16(1 \mathrm{H}, \mathrm{d}, J=9.2 \mathrm{~Hz}, \mathrm{H} 6), 8.26$ $(1 \mathrm{H}, \mathrm{d}, J=9.2 \mathrm{~Hz}, \mathrm{H} 5), 8.98(1 \mathrm{H}, \mathrm{d}, J=5.0 \mathrm{~Hz}, \mathrm{H} 3), 10.81(1 \mathrm{H}, \mathrm{d}, J=8.5 \mathrm{~Hz}$, $\mathrm{H} 1) ;{ }^{13} \mathrm{C}-\mathrm{NMR}\left(\mathrm{CDCl}_{3}, 400 \mathrm{MHz}\right) \delta: 21.9,31.4,40.2,107.8,116.3,120.2$, $120.3,121.1,124.7,135.5,136.5,140.9,147.3,148.3,168.1$. IR $\mathrm{cm}^{-1}=v_{\mathrm{C}=\mathrm{O}}=1639, \mathrm{MS}=252(6 \%), 250(3 \%), 154(100 \%), 149(60 \%), 136$ (85\%). Anal. Calcd for $\mathrm{C}_{15} \mathrm{H}_{13} \mathrm{~N}_{3} \mathrm{O}: \mathrm{C}, 71.71 ; \mathrm{H}, 5.18 ; \mathrm{N}, 16.73$. Found: $\mathrm{C}$, $71.59 ; \mathrm{H}, 5.13 ; \mathrm{N}, 16.68$.

11-Hydroxy-7-methyl-pyrido $\left[3^{\prime}, 4^{\prime}-4,5\right]$ pyrrolo[2,3-c]quinoline 26 Compound 22 ( $40 \mathrm{mg}, 0.16 \mathrm{mmol}$ ) was added to a supension of $\mathrm{Pd} /$ carbon $10 \%(100 \mathrm{mg})$ in diphenylether $(20 \mathrm{ml})$ and the reaction mixture was refluxed under nitrogen for $1 \mathrm{~h}$. Still hot, the reaction mixture was filtered in order to eliminate $\mathrm{Pd} / \mathrm{carbon}$, which was washed with a hot mixture of dichloromethane and methanol (50/50). Dichloromethane and methanol were evaporated in vacuo and the diphenylether containing the final product was chromatographed on silica gel using dichloromethane as eluent to eliminate diphenylether and dichloromethane and a gradient of methanol to give 26 as a yellow oil: $30 \%$. ${ }^{1} \mathrm{H}-\mathrm{NMR}\left(\mathrm{CDCl}_{3}, 400 \mathrm{MHz}\right) \delta$ : $4.01\left(3 \mathrm{H}, \mathrm{s}, \mathrm{CH}_{3}\right)$, $6.91(1 \mathrm{H}, \mathrm{d}, J=7.1 \mathrm{~Hz}, \mathrm{H} 8), 7.77(1 \mathrm{H}, \mathrm{d}, J=6.9 \mathrm{~Hz}, \mathrm{H} 9), 7.90(2 \mathrm{H}, \mathrm{m}, \mathrm{H} 2$ and $\mathrm{H} 3), 8.18(1 \mathrm{H}, \mathrm{d}, J=8.0 \mathrm{~Hz}, \mathrm{H} 4), 9.43(1 \mathrm{H}, \mathrm{s}, \mathrm{H} 6), 10.1(1 \mathrm{H}, \mathrm{d}$, $J=8.4 \mathrm{~Hz}, \mathrm{H1}) ;{ }^{13} \mathrm{C}-\mathrm{NMR}\left(\mathrm{CDCl}_{3}, 400 \mathrm{MHz}\right) \delta: 31.2,96.6,110.5,119.0$, $120.1,123.5,129.3,129.8,130.6,131.4,132.8,133.3,134.2,136.7,152.20$ IR $\mathrm{cm}^{-1}=v_{\mathrm{O}-\mathrm{H}}=2800-3600, \mathrm{MS}=250(100 \%), 176(30 \%), 154(35 \%)$, $136(34 \%)$. Anal. Calcd for $\mathrm{C}_{15} \mathrm{H}_{11} \mathrm{~N}_{3} \mathrm{O}: \mathrm{C}, 72.29 ; \mathrm{H}, 4.42 ; \mathrm{N}, 16.87$. Found: C, $72.39 ; \mathrm{H}, 4.44 ; \mathrm{N}, 16.87$

11-Hydroxy-7-methyl-pyrido[3', $\left.4^{\prime}-4,5\right]$ pyrrolo[3,2-f]quinoline 27 This compound was obtained in $32 \%$ yield according to the procedure described for compound 26. Yellow oil. ${ }^{1} \mathrm{H}-\mathrm{NMR}\left(\mathrm{CDCl}_{3}, 400 \mathrm{MHz}\right) \delta: 3.87$ (s, 3H, $\left.\mathrm{CH}_{3}\right), 6.54(\mathrm{~d}, 1 \mathrm{H}, J=7.1 \mathrm{~Hz}, \mathrm{H} 8), 7.27(\mathrm{~d}, 1 \mathrm{H}, J=7.1 \mathrm{~Hz}, \mathrm{H} 9), 7.5$ $(\mathrm{m}, 2 \mathrm{H}, \mathrm{H} 2$ and $\mathrm{H} 3), 7.76(\mathrm{~d}, 1 \mathrm{H}, J=9.1 \mathrm{~Hz}, \mathrm{H} 6), 8.0(\mathrm{~d}, 1 \mathrm{H}, J=9.1 \mathrm{~Hz}, \mathrm{H} 5)$, $8.74(\mathrm{~m}, 1 \mathrm{H}, \mathrm{H1}) ;{ }^{13} \mathrm{C}-\mathrm{NMR}\left(\mathrm{CDCl}_{3}, 400 \mathrm{MHz}\right) \delta: 30.3,94.3,114.1,119.3$, $121.2,124.9,126.7,127.2,130.8,131.4,136.0,138.0,145.2,146.0,147.7$. IR cm $\mathrm{cm}^{-1}=v_{\mathrm{O}-\mathrm{H}}=2800-3600, \mathrm{MS}=250(100 \%), 176(40 \%), 154(65 \%)$, 136 (45\%). Anal. Calcd for $\mathrm{C}_{15} \mathrm{H}_{11} \mathrm{~N}_{3} \mathrm{O}: \mathrm{C}, 72.29 ; \mathrm{H}, 4.42 ; \mathrm{N}, 16.87$. Found: C, $72.38 ; \mathrm{H}, 4.46 ; \mathrm{N}, 16.91$.

Biological Assay Doxorubicine hydrochloride (Pharmacia, St-Quentin en Yvelines, France), RPMI 1640 medium and fetal calf serum (Polylabo, Paris, France) were used in this study. 3-(4,5-dimethylthiazol-2-yl)-2,5diphenyltetrazolium bromide (MTT) was provided by Sigma (St-Quentin Fallavier, France). All other reagents were of analytical grade and were obtained from commercial sources.

Cells and Culture: The human leukemic cell line K 562 was obtained from the American type culture collection (Rockville, MD, U.S.A.). The human ovarian carcinoma cell line A 2780 was generously given by Dr P. Canal (Centre Claudius Regaud, Toulouse). The doxorubicine resistant cell line A $2780 \mathrm{R}$ was established by the continuous exposure of cells to gradu- ally increasing concentrations of doxorubicine and was maintained in a medium supplemented with doxorubicin at $0.1 \mu \mathrm{g} / \mathrm{ml}$. The MDR phenotype expression of A $2780 \mathrm{R}$ cell lines was assessed by an immunohistochemistry method, using the two P-glycoprotein specific murine monoclonal antibody C219 (Cantocor, Malvern, PA, U.S.A.) and JSB1 (Tebu, Le Perray en Yvelines, France). Cultures were grown in RPMI 1460 medium supplemented with $10 \%$ fetal calf serum, antibiotics and glutamine at $37{ }^{\circ} \mathrm{C}$ in a humidified atmosphere containing $5 \% \mathrm{CO}_{2}$.

Cytotoxicity Assay: In all the experiments, K 562 and A 2780 cells were seeded at a final density of 5000 cells/well in 96 well microtiter plates and were treated with drugs (doxorubicine and compound 16, 17, 22, 23, 26, 27). Seven dilutions were used for each drug. After $96 \mathrm{~h}$ of incubation, $10 \mu \mathrm{l}$ of MTT solution in PBS $(5 \mathrm{mg} / \mathrm{ml}$, Phosphate-buffer saline $\mathrm{pH} 7.3)$ were added to each well and the wells were exposed to $37^{\circ} \mathrm{C}$ for $4 \mathrm{~h}$. This colorimetric assay is based on the ability of live and metabolically unimpaired tumor-cell targets to reduce MTT to a blue formazan product. Then, $100 \mu \mathrm{l}$ of a mixture of isopropanol and $1 \mathrm{~m}$ hydrochloric acid $(96 / 4, \mathrm{v} / \mathrm{v})$ were added to each well. After $10 \mathrm{~min}$ of vigourous shaking so as to solubilize formazan crystals, the absorbance was measured on a microculture plate reader (Dynatech MR 5000, France) at $570 \mathrm{~nm}$. For each assay, at least three experiments were performed in triplicate. The resistance factor was calculated from the ratio between the $\mathrm{IC}_{50} \%$ growth-inhibitory concentrations $\left(\mathrm{IC}_{50} \mathrm{val}-\right.$ ues) recorded from A $2780 \mathrm{R}$ and A $2780 \mathrm{~S}$ cells, respectively, for the following tested drugs: doxorubicine, compounds 16, 17, 23, 26, 27.

\section{References}

1) Goodwin S., Smith A. F., Horning E. C., J. Am. Chem. Soc., 81, 1903-1906 (1959).

2) Chu Y., Hsu M. T., Nucleic Acids Res., 20, 4033- 4038 (1992).

3) Monnot M., Mauffret O., Simon V., Lescot E., Psaume B., Saucier J. M., Charra M., Belehradek J., Fermandjian S., J. Biol. Chem., 25, 1820-1829 (1991).

4) Nguyen C. H., Lhoste J. M., Lavelle F., Bissery M. C., Bisagni E., J. Med. Chem., 33, 1519-1528 (1990).

5) Nabiev I., Chourpa I., Riou J. F., Nguyen C. H., Lavelle F., Manfait M., Biochemistry, 33, 9013-9023 (1994).

6) Riou J. F., Fossé P., Nguyen C. H., Kragh Larsen A., Bissery M. C., Grondard L., Saucier J. M., Bisagni E., Lavelle F., Cancer Res., 53, 5987-5993 (1993).

7) Da Settimo A., Da Settimo F., Marini A. M., Primofiore G., Salerno S., Viola G., Dalla Via L., Magno S. M., Eur. J. Med. Chem., 33, 685696 (1998).

8) Dalla Via L., Gia O., Magno S. M., Da Settimo A., Primofiore G., Da Settimo F., Simorini F., Marini A. M., Eur. J. Med. Chem., 37, 475486 (2002)

9) Dupuy M., Pinguet F., Chavignon O., Chezal J. M., Teulade J. C., Chapat J. P., Blache Y., Chem. Pharm. Bull., 49, 1061-1065 (2001).

10) Dupuy M., Blache Y., Bailly C., Poujol S., Chapat J. P., Pinguet F., Anticancer Res., 22, 3365-3371 (2002).

11) Aragon P. J., Chezal J. M., Chavignon O., Teulade J. C., Blache Y., Heterocycles, 60, 551-561 (2003).

12) Blache Y., Benezech V., Chezal J. M., Boule P., Viols H., Chavignon O., Teulade T. C., Chapat J. P., Heterocycles, 53, 905-916 (2000).

13) Aragon P. J., Chezal J. M., Chavignon O., Teulade J. C., Chapat J. P., Blache Y., Heterocyclic Commun., 9, 189-194 (2003).

14) Gardette D., Gramain J. C., Lepage M. E., Troin Y., Can. J. Chem., 67, 213-219 (1989).

15) Sekar M., Vanitha S., Rajendra Prasad K. J., Zeitschrift fuer Naturforschung B: Chemical Sciences, 49, 687-690 (1994).

16) Scheiber P., Nemes P., Heterocycles, 41, 2189-2194 (1995).

17) Jeyaraman R., Senthilkumar U. P., Tetrahedron Lett., 35, 9279-9280 (1994).

18) Shanmugasundaram K., Rajenda Prasad K. J., Heterocycles, 51, 2161-2169 (1999). 